This manuscript is a preprint. Please note that the manuscript is under review and it has yet to been formally accepted for publication. Subsequent versions of this manuscript may, thus, have slightly different content. If accepted, the final version of this manuscript will be available via the 'Peer-reviewed Publication DOI' link on the right-hand side of this webpage. Please, feel free to get in contact. We welcome feedback. 


\title{
Fault-controlled base-of-scarp deposits
}

\author{
Domenico Chiarella ${ }^{1}$, Walter Capella ${ }^{1}$, Sergio G. Longhitano ${ }^{2}$, Francesco Muto ${ }^{3}$ \\ ${ }^{1}$ Clastic Sedimentology Investigation (CSI), Department of Earth Sciences, Royal Holloway, University of London, \\ Egham, UK; domenico.chiarella@rhul.ac.uk \\ ${ }^{2}$ Department of Sciences, University of Basilicata, Potenza, Italy \\ ${ }^{3}$ Dipartimento di Biologia, Ecologia e Scienza della Terra, University of Calabria, Italy
}

\section{ABSTRACT}

The term base-of-scarp is proposed for those submarine deposits controlled by a fault and physically disconnected from their more proximal counterpart located on the footwall, although genetically linked to it. These systems differ from conventional fault-controlled deltas, such as shoal- and Gilberttype, because they are entirely subaqueous and lack equilibrium morphology -a steady-state in which the system grows in size without altering its shape. We present field examples of fault-controlled baseof-scarp deposits from the Crati Basin and the Messina Strait (southern Italy) consisting of clastic wedges with primary inclined bedding. Beds are composed of immature coarse-grained gravel and sand, lack structures representative of wave-action, and reflect gravity-driven processes such as debris flow, debris fall, and high-density turbidity currents. A diagram for fault-controlled deposits is presented, including their steady- and unsteady-states, and the conceptual conditions under which a base-of-scarp system might evolve into Gilbert-type or shoal-water systems.

\section{INTRODUCTION}

Fault-controlled systems have long been studied to improve the understanding and prediction of sandand gravel-body architectures in analogous subsurface systems (Colella, 1998a; Ethridge and Wescott, 1984; Lewis et al., 2015). Such fault-controlled deposits are important in basin analysis because they provide a record of tectonic events and base level changes that operated during basin evolution (Hardy et al., 1994; Gobo et al., 2015). However, existing classification schemes and models for faultcontrolled systems (e.g. Massari and Colella, 1988) put low emphasis on the embryonic phase of 
unsteady-state development. Embryonic phase that develops when sediments are sourced along a fault scarp directly into relatively deep-water basins and sediment-gravity transport dominates down fault scarps forming accumulations at its base (Nemec, 1990). The resulting base-of-scarp deposit does not generate sufficient sediment volume to reach base level and to continue to evolve as a delta with a subaerial or shallowly submerged distributary plain.

Although in the literature there has been little attention to fault-controlled base-of-scarp deposits, they are common in many syn-rift basins characterizing their early phases. Accordingly, our understanding of the tectono-stratigraphic evolution is poor despite the unsteady base-of-slope deposits contain several useful information. The reason can be that they are relatively thin compared to other syn- and post-rift deposits, poorly imaged in seismic reflection data, and typically included and interpreted within the well-known steady-state deposits in which they evolve.

Deposits assimilable to base-of-scarp systems have been described in different geological contexts like fjords or tectonically controlled deep environments in outcrop (e.g. Wollaston Forland Group, Greenland) and subsurface examples (e.g. Brae Formation, North Sea), and referred to as underwater conical delta, apron or submarine fan (Ethridge and Wescott, 1984; Surlyck, 1984; Leeder and Gawthorpe, 1987; Prior and Bornhold, 1988; Nemec, 1990; Henstra et al., 2016; Turner and Connell, 2018; Cullen et al., in press). Syn-rift deposits evolving through unsteady and steady-state phases can be recognised, among others, in published examples of rifted deposit of the Bohai Bay Basin (e.g. Jia et al., 2019), the Crati Basin (e.g. Colella, 1988b), and the Gulf of Suez (e.g. Lewis et al., 2015) (Fig. 1), although, many cases can be hidden in examples where the published iconographic material or description doesn't easily allow their identification.

The proposed unsteady-state (i.e. base-of-scarp deposit) is characterised by the evolution in morphology and internal geometry during basin filling (Prior and Bornhold, 1988) gradually reducing its slope angle (Nemec, 1990), eventually aggrading close to the base level and potentially evolving 
into either a shoal-water or Gilbert-type delta system with morphologies that grow in steady-state conditions.

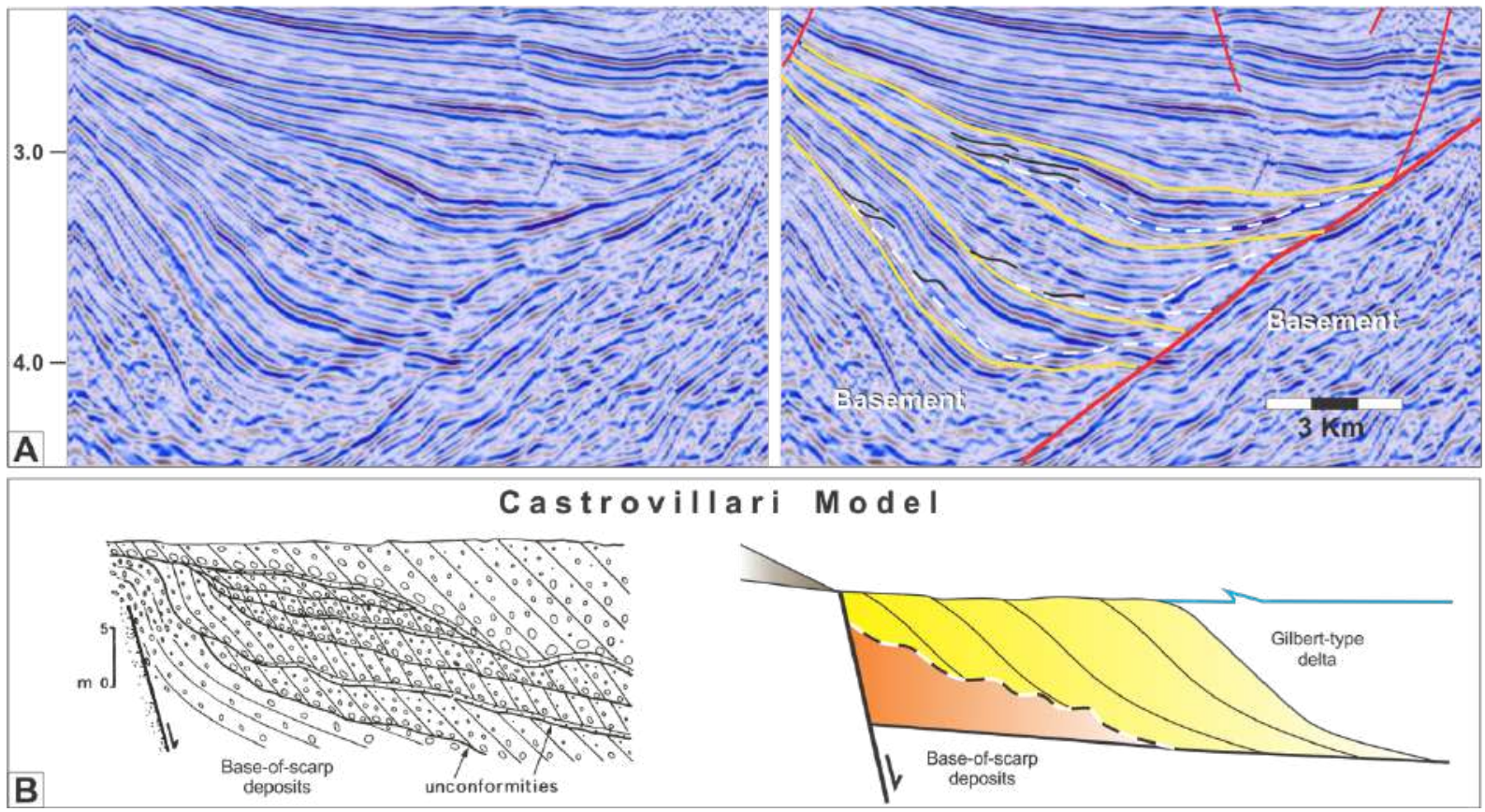

Figure 1 - Subsurface and outcrop examples of fault-controlled systems developing a base-of-slope alike deposits on which Gilbert-type systems develops. A) Vertically stacked units of the Bohai Bay (China) extensional system producing unsteady wedge-shaped deposits evolving to steady-state Gilbert systems. The Gilbert systems develop above an unconformity surface (dashed line) (modified from Jia et al., 2019). B) The Castrovillari Model proposed by Colella (1988b) for the vertically stacked systems recognised in the Crati Basin (Italy). Accumulation assimilable to the proposed base-of-scarp deposits is reported during the early stage. Important to highlight as in both cases, the interpreted base-of-scarp deposits are capped by an unconformity surface separating the unsteady and steady-state systems.

In this paper, we investigate fault-controlled base-of-scarp deposits from two study areas to document their geometric and sedimentological characters and the transition to steady-state deltas that might occur if sediment accumulation exceeds tectonically-created nearshore accommodation. Our hypothesis is that by defining base-of-scarp deposits and comparing them with published models of shoal-water and Gilbert-type delta systems in the literature, we can (i) distinguish features such as internal architecture and facies distribution, and (ii) provide a frame of reference for future studies on fault-controlled deltas. We propose a BGS diagram with Base-of-scarp (B), Gilbert (G) and Shoal-water (S) fault-controlled delta types. The diagram includes their initial unsteady-state and evolution paths towards steady-state. Evolution that can potentially go backward to unsteady-state if accommodation 
outpaces sediment supply producing vertically stacked systems (e.g. Colella, 1988b; Dorsey et al., 1995;

Garcia-Garcia et al., 2006).

\section{GEOLOGICAL SETTING}

\section{Tectonics and structure of the Crati Basin and Messina Strait}

Fault-controlled deposits develop in tectonically active basins forming tens of meters to hundreds of meters thick successions. Usually, the higher syn-depositional cumulative displacement created by the fault, the thicker the delta stack (Hardy et al., 1994). Our field examples are located in two basins (Crati and Messina, southern Italy, Figs. 2 and 3) that were active during the Plio-Pleistocene and associated with the last tectonic displacement of the Calabrian Arc (Monaco and Tortorici, 2000; Van Dijk et al., 2000; Tansi et al., 2007).
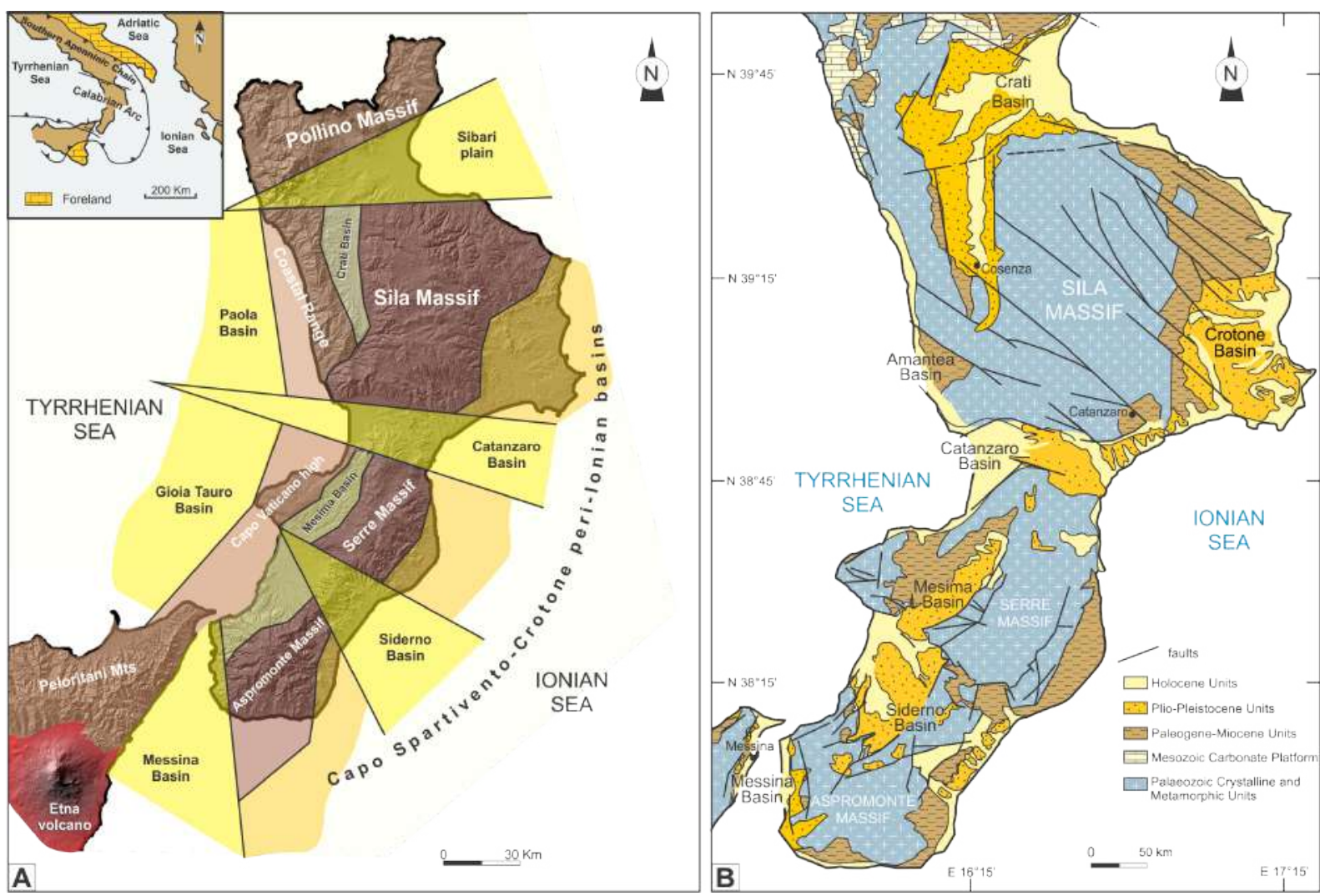

Figure 2 - A) Plio-Pleistocene block-segmentation of the Calabrian Arc with in yellow the resulting sedimentary basins (Chiarella, 2016 after Ghisetti, 1979). B) Simplified geological map of the Calabrian Arc, Southern Italy (modified after Longhitano et al., 2012). 
The Crati Basin and the Messina Strait represent two extensional basins related to the Late PlioceneEarly Quaternary block segmentation of the Calabrian Arc interpreted as the effect of the migration of the orogen towards the forearc lonian Basin (Ghisetti, 1979; van Dijk et al., 2000; Tansi et al., 2007). The Crati Basin, which is located in the northern part of the Calabrian Arc, is an L-shaped basin developed since Early-Pleistocene as response to the W-E extension that characterise the western portion of the Calabrian Arc (Figs. 2 and 3A; Turco et al., 1990). The Crati Basin trends N-S in the southern portion, with an E-W oriented component in the northern part. The basin margin consists of Paleozoic crystalline rocks of the Sila Massif on the east, crystalline and sedimentary rocks of the Coastal Range in the west and Meso-Cenozoic carbonate deposits in the north. The Crati Basin hosts well-known examples of fault-controlled shoal-water and Gilbert-type deltas (Colella, 1988b), and in the present study we focus on facies variations and vertical evolution of the lower portion of the EarlyMiddle Pleistocene Civita section (Fig. 3A). The Civita section developed in the northern sector of the Crati Basin along a fault-segment of the $15-\mathrm{Km}$-long Pollino Fault, and pertain to the Pleistocene Synthem (PIS) defined by Spina et al. (2011) (Fig. 3A). The Pollino Fault has an oblique normal-sinistral kinematics (Chiarabba et al., 2016; Ghisetti \& Vezzani, 1982; Monaco \& Tansi, 1992; Tansi et al., 2007; Van Dijk et al., 2000) forming a SW facing fault scarp that favoured the formation of several vertically stacked deltaic units having a total thickness of $\sim 300 \mathrm{~m}$ (Colella, 1988b). The Civita section has been previously interpreted as a stacked Gilbert delta succession referred to as the Castrovillari model (Colella, 1988a) - a Gilbert-type delta succession recording several episodes of tectonic activity in form of erosive, bounding sequences separated by unconformities related to the reactivation of normal faults. However, the lower portion of the Civita section shows neither a bottomset nor a topset but only inclined beds forming a wedge-shaped body characterised by an upward decrease in strata dip, and thinning towards and onlapping against the fault scarp (Figs. $3 \mathrm{~A}$ and $4 \mathrm{~A}-\mathrm{C}$ ). 

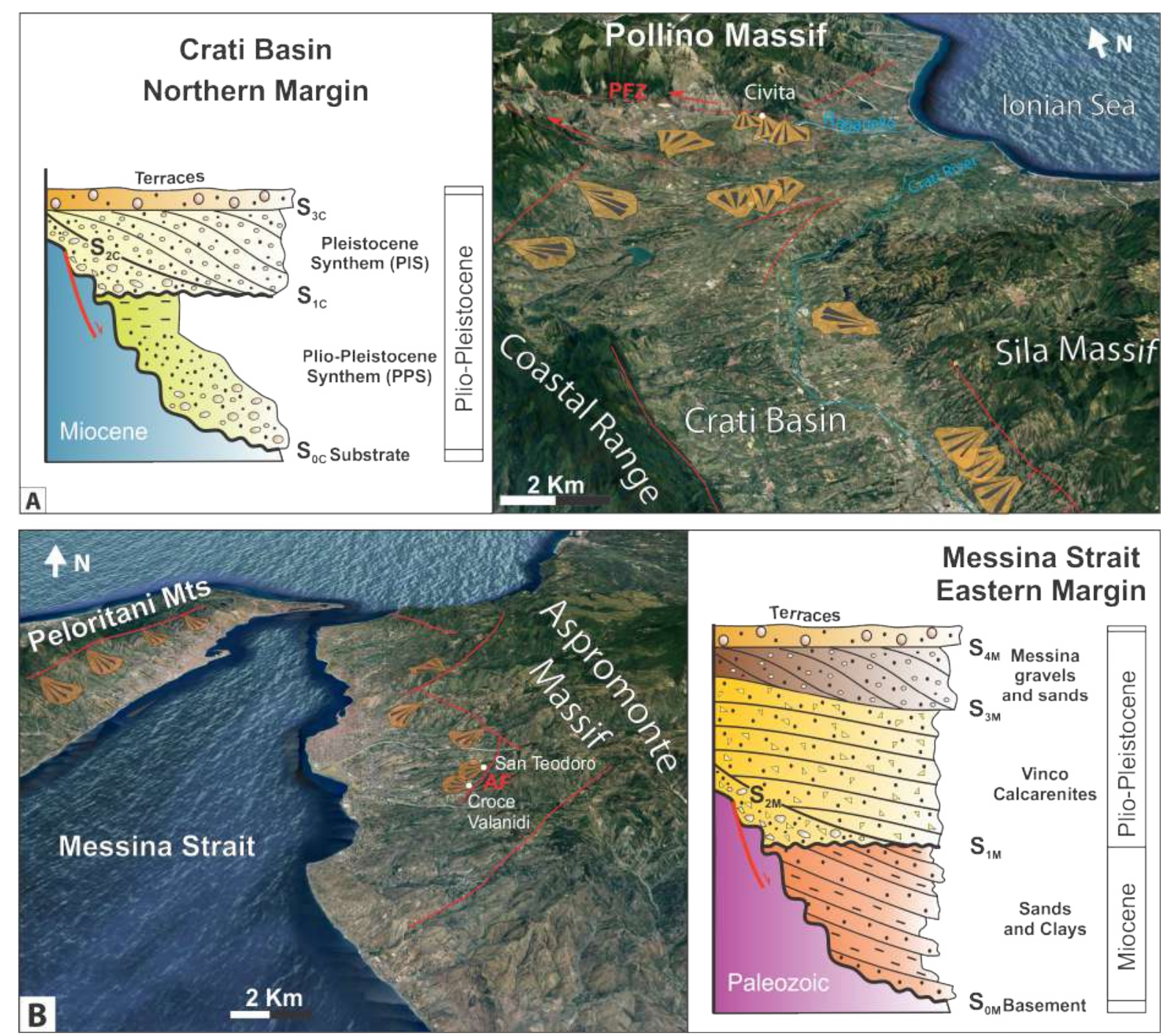

Figure 3 - A) Schematic stratigraphic column of the northern margin of the Crati Basin, and map showing the distribution of fault-controlled Plio-Pleistocene systems in the eastern and northern portion of the Crati Basin. B) Schematic stratigraphic column and map showing the distribution of fault-controlled systems in the eastern margin of the Messina Strait. PFZ: Pollino Fault Zone. AF: Armo Fault.

The Messina Strait developed during a Pliocene phase of structural-controlled narrowing, related to the tectonic activity of an NNE-SSW-oriented faults system known as "Siculo-Calabrian Rift Zone" (Ghisetti, 1984, 1992; Monaco et al., 1996; Monaco and Tortorici, 2000; Catalano et al., 2008; Fig. 2). Faults system that dissect the Paleozoic metamorphic rocks of the Peloritani-Aspromonte Massifs and controlled the evolution and accumulation of deposits along the basin margins through a synsedimentary activity. The studied Messina Strait examples comprise base-of-scarp deposits of the Croce Valanidi and San Teodoro sections (Figs. 3B and 4D-E) located on the eastern margin of the strait along the Armo Fault. This structure is a NE-striking normal lineament that controlled the location of 
depocenters and the abrupt along-strike thickness, and facies change of the Pleistocene deposits. On the Armo Fault, the fault throw is $\sim 350 \mathrm{~m}$ with a time-averaged throw rate of $0.7+0.3 /-0.2 \mathrm{~mm} \mathrm{a}{ }^{-1}$ based on terrace offsets (Roda-Boluda and Whittaker, 2017). During the initial extensional phases, the Armo Fault produced a fault-propagation fold, which controlled the deposition of the base-of-scarp deposits. These deposits have been referred in the literature as intraformational breccias and masswasting deposits associated with subaqueous steep cliffs (Longhitano, 2018 and references therein). Base-of-scarp deposits pass upward to shallower deposits pertaining to the Plio-Pleistocene Vinco Calcarenites Unit, which despite the name actually consists of a compositional mixing of bioclastic and siliciclastic sediments (sensu Chiarella et al., 2017), or to bathyal clays (Fig. 3B).
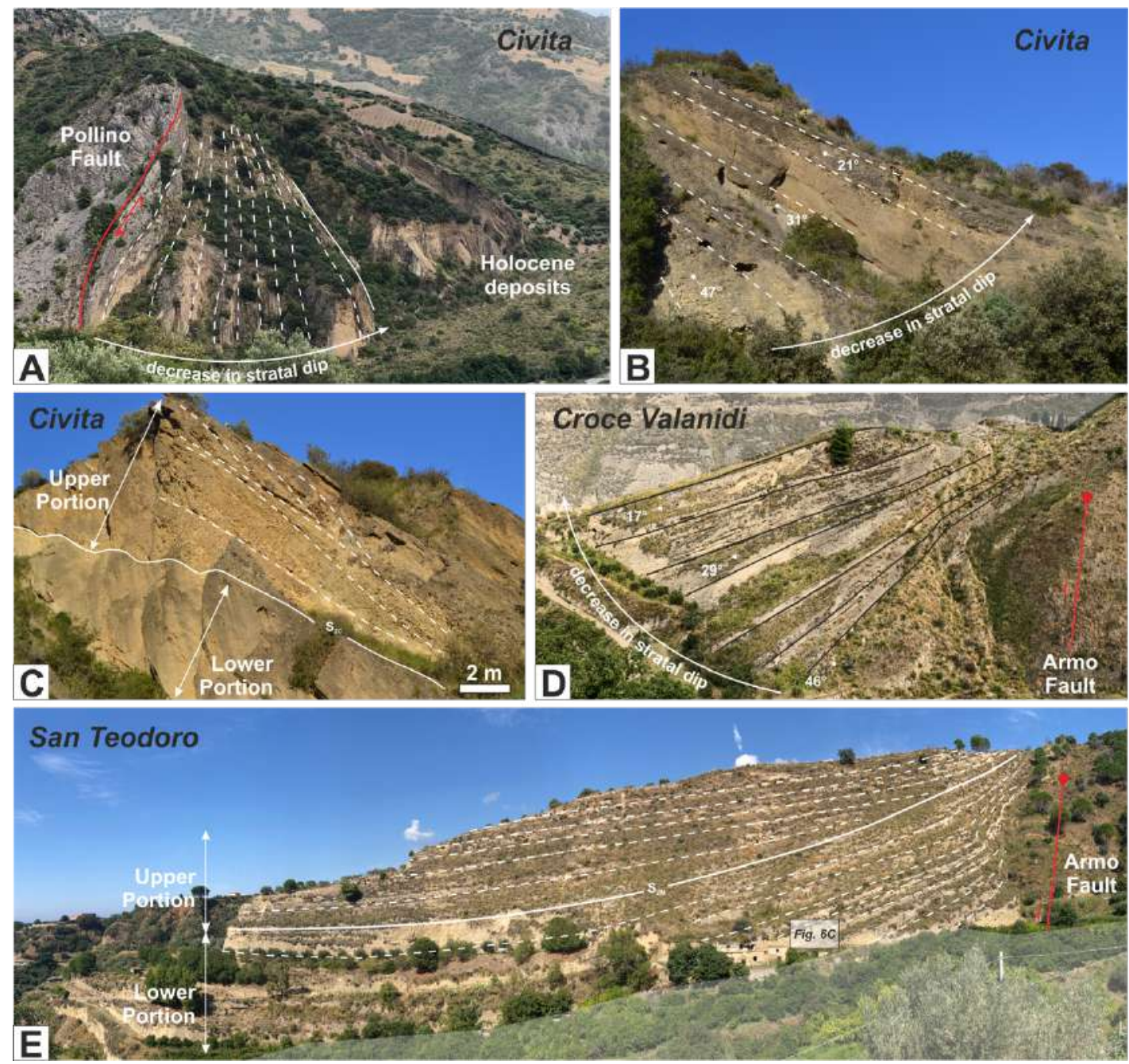

Figure 4-Wedge-shaped architectures of base-of-scarp systems showing a general upward decrease in the strata dip. Upward transition between the base-of-scarp deposits of the lower portion to the Gilbert-type (C) and shoal-water (E) systems of the upper portion. Transition marked by the presence of an angular unconformity and change in strata geometries. 


\section{METHODOLOGY}

To investigate the unsteady-state base-of-scarp deposits and their evolution to steady-states, the following methods are used: (i) drawing of sedimentary logs resulted from bed-by-bed logging; followed by conventional sedimentological analysis; and (ii) line-drawing performed on panoramic photos to investigate the proximal to distal variation of bedding attitude and geometry. We specifically selected logging paths to detect variations in facies along strike and dip, with the local logging route depending on accessibility of the outcrop. Sedimentological logs measured in the field have been combined to form a representative vertical sedimentary succession of the base-of-scarp delta (Fig. 5).

The studied units are easily distinguished and laterally followed in the field in the two studied areas and they have been locally identified in several previous studies (e.g. Colella, 1988b; Barrier, 1986; Ghisetti, 1992; Roda-Boluda and Whittaker, 2017; Longhitano, 2018).

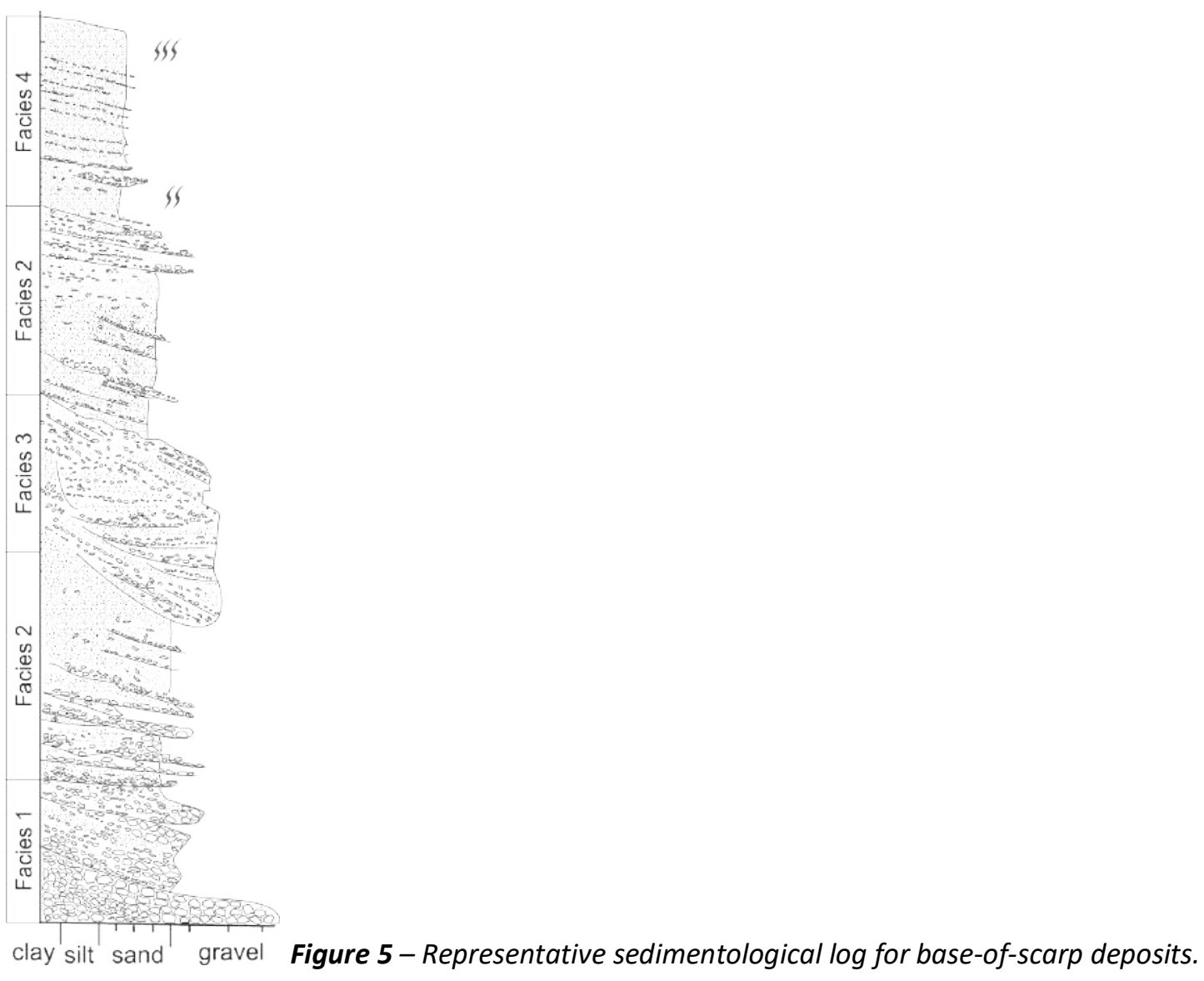




\section{ANATOMY OF BASE-OF-SCARP DEPOSITS}

\section{Civita section (Crati Basin)}

\section{Stratal architecture and facies}

Early-Middle Pleistocene coarse-grained deposits of the Civita section unconformably overlie Mesozoic carbonates along the scarp of the Pollino Fault. Depositional architectures indicate a dominant southwest evolution of the system. Towards the south, the Early-Middle Pleistocene deposits are overlain by Middle-Upper Pleistocene lacustrine sediments. Along the Raganello Stream (Fig. 4A), the Early-Middle Pleistocene coarse-grained deposits are overturned and unconformably overlain by Late Pleistocene-Holocene fluvial terrace deposits. Overturned strata are related to transpressional jog along the Pollino fault zone (Catalano et al., 1993; Ferranti et al., 2009) active after the deposition of the Early-Middle Pleistocene coarse-grained deposits of the Civita section.

The lower portion of the Civita section shows a wedge-shaped geometry characterised by a gradual upwards decrease in strata dip within the unit. In particular, a difference of $\sim 25^{\circ}$ is appreciable between the lower and the upper strata suggesting a southward thickening of the unit (Figs. 4A-C).

In the proximal and lowermost portion of the system, strata consist of gravel- to pebble-sized breccias supported by a fine- to medium-grained sand (Facies 1; Fig. 6A). Moving upwards, strata become more organized showing an alternation of conglomerate and sandstone beds (Facies 2; Figs. 6B-D). Gravel beds are up to $50 \mathrm{~cm}$ thick and consist of poorly- to moderately-sorted, matrix- to clast-supported, sub-rounded to rounded pebbles and cobbles conglomerates. Matrix is sand-gravel grade, and locally clasts are imbricated. The sandstone beds consist of coarse-grained moderately- to poorly-sorted, subangular to sub-rounded arenite. Locally, scattered granules and pebbles occur. Unfortunately, the vertical attitude of the strata doesn't allow to properly evaluate the proximal to distal variation of the facies respect to the fault scarp nor to infer the primary depositional dip angle of the paleo-slope. The top of the lower portion is characterised by an angular unconformity locally draped by a $50 \mathrm{~cm}$ thick bed made of silt and fine-grained sand present as solitary bed (Fig. 7). Clasts composing the Civita system derive mainly from the Meso-Cenozoic carbonate units exposed along the margin. 

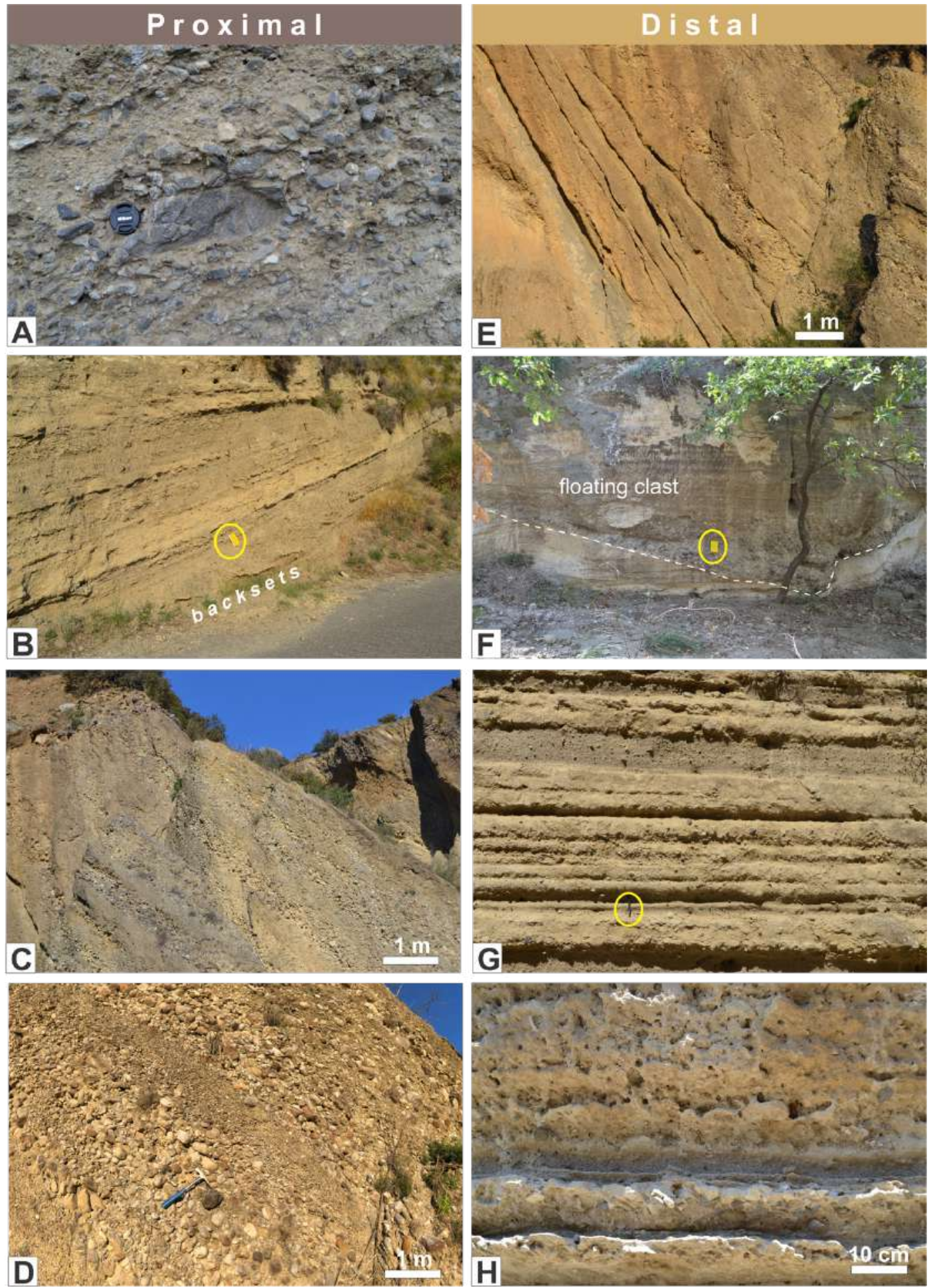

Figure 6 - Close-up photographs of sedimentary facies in proximal ( $\sim 50 \mathrm{~m}$ away from the scarp) and distal positions (300 to 450m away from the scarp). Facies 1: (A) Non-graded pebbly sandstone with lenticular intervals of breccia and clast-supported conglomerate showing a coarse-tail inversely grade trend. Facies 2 : (B-D) Tabular alternation of clast-supported conglomerates and sandstone beds at the San Teodoro (B) and Civita (C-D) sections. Upslope migrating chute-fill backsets characterise the lower part of the insert $B$. (C) Close-up view of the conglomeratic-sandstone alternation. (E) In the distal portion of the system, stratified medium- to coarse-grained sandstones dominate the Facies 2. Facies 3: (F) Conglomeratic channel with large floating clast in the upper part cutting through, and covered by, tabular sandstones. Facies 4: (G) Tabular fine- to medium-grained sandstones with isolated clasts; $(H)$ Bioturbated intervals (Thalassinoides). 
At the top of the lower portion ( $\sim 100 \mathrm{~m}$ above the basal contact), an angular unconformity $\left(\mathrm{S}_{2 \mathrm{C}}\right)$ separates the wedge-shaped unsteady base-of-scarp deposits from an upper portion characterised by prograding foreset elements (Fig. 7). Foresets downlap onto the base-of-scarp deposits and are part of the younger steady-state Gilbert-type delta pertaining to the Castrovillari model defined by Colella (1988b). Important to highlight is that the distinctive character of the Castrovillari model is the recognition of vertically-stacked units separated by major irregular surfaces related to slides resulted from high-magnitude subaqueous slip events (Colella, 1988b).

Sediments derives mainly from the Meso-Cenozoic carbonate and flysch units representing the substrate of the fault-controlled basin margin.

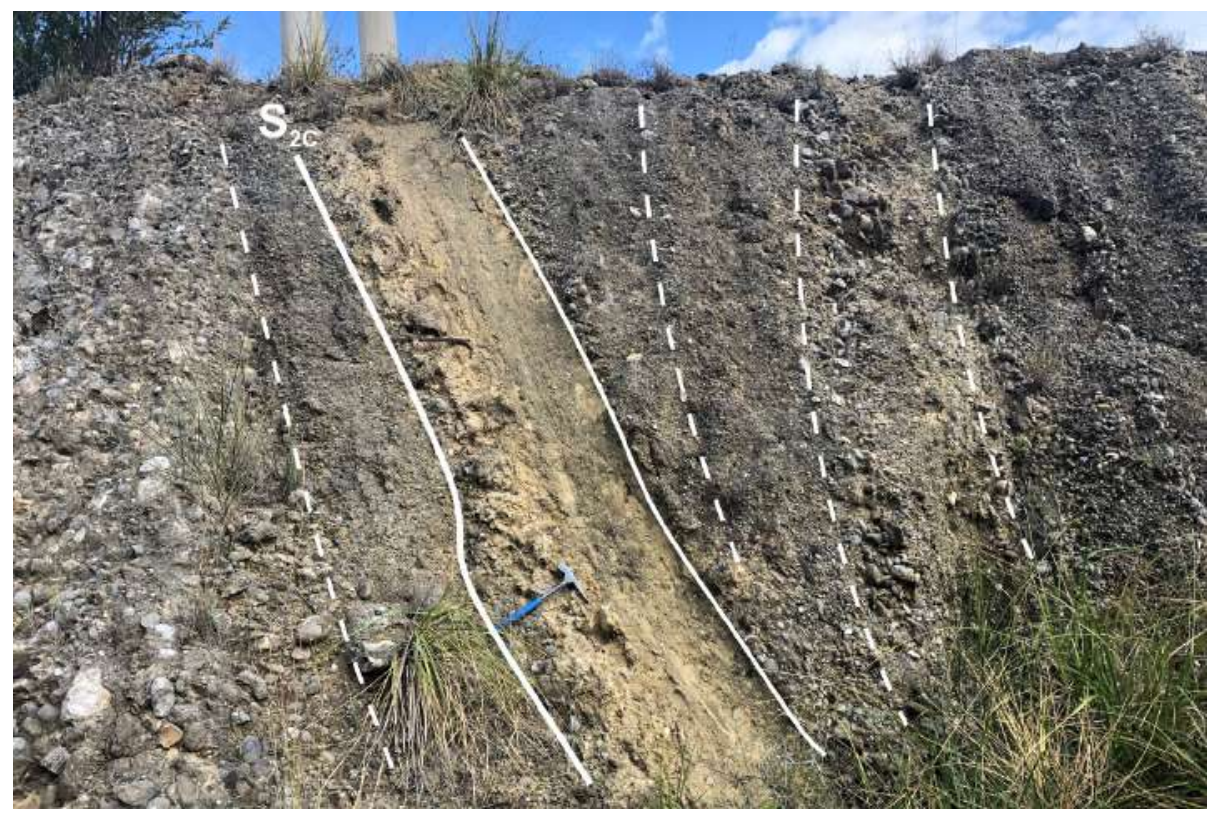

Figure 7 - Stratigraphic transition between the unsteady base-of-scarp deposits and the steady-state Gilbert-type delta. The transition is marked by the $S_{2}$ unconformity topped by fine-grained sand.

Depositional processes are interpreted to be dominated by sediment gravity flows, such as gravel-rich inertial grain flows to non-cohesive debris flows, and high-density turbidity currents (Nemec, 1990).

The presence of an angular unconformity between the pre-rift Mesozoic carbonates and the lowermost syn-rift deposits of the Civita section along the Pollino Fault suggests that a pronounced relief was associated with this structure at the onset of syn-rift deposition. Based on the change of the 
dip angle between the lower and the upper strata of the lower portion, we suggest that the Pollino Fault was active during the sedimentation controlling the accumulation of the base-of-scarp deposits of the Civita section as indicated by the presence of the intraformational unconformity $\mathrm{S}_{2 c}$. Accordingly, base-of-scarp deposits were deposited in a syn-rift wedge that thinned towards the Pollino Fault (Figs. $6 A-B)$.

The presence of fine-grained deposits above the unconformity $\left(S_{2 c}\right)$ suggests a rapid increase of the water depth probably related to the activity of the controlling fault (Fig. 4). Fault activity responsible also for the re-adjustment of the depositional profile towards a less inclined slope due to the redistribution of the slumped deposits. In fact, the unconformity separating the unsteady base-of-scarp deposits from the steady-state Gilbert-type delta results from the combination of the topography generated after the emplacement of the first deposits and the deformation imparted by the fault displacement. These processes produced a change in the depositional profile resulting in a depositional angle suitable for the development of a Gilbert system.

\section{Croce Valanidi and San Teodoro sections (Messina Strait)}

\section{Stratal architecture and facies}

The Plio-Pleistocene syn-rift Vinco Calcarenites Unit of the Croce Valanidi and San Teodoro sections lies nonconformably on top of Paleozoic metamorphic rocks of the Peloritani-Aspromonte Massifs along the Armo Fault, and though an angular unconformity on top of Miocene deposits in the distal area. The nonconformable surface represents the base syn-rift unconformity $\mathrm{S}_{0 \mathrm{M}}$ (Fig. 3B). Depositional architectures and elements (e.g. channels) indicate a west-northwest evolution of the system, almost perpendicular to the present-day orientation of the Messina Strait (Fig. 3). The Vinco Calcarenites are topped by middle Pleistocene deltaic deposits of the Messina Gravels and Sands Formation (Fig. 3B). The identification of the boundary between the Vinco Calcarenites Unit and the Messina Gravels and Sands Fm is facilitated in the field by the mixed bioclastic-siliciclastic nature of the Vinco Calcarenites. 
Mixed composition representing a distinctive feature of many Plio-Pleistocene deposits accumulated in the Mediterranean area (e.g. Massari and Chiocci, 2006; Yesares and Aguirre, 2004; Chiarella et al., 2012; Longhitano et al., 2012; Pepe and Gallicchio, 2013; Longhitano et al., 2014; Nalin et al., 2016; Rossi et al., 2018), and would reflect specific conditions of sediment deposition very sensitive for recording local hydrodynamics processes (Chiarella and Longhitano, 2012; Chiarella et al., 2019).

The base-of-scarp deposits of the Croce Valanidi and San Teodoro sections are characterised by a wedge-shaped geometry exhibiting a gradual upward decrease in strata dip (Figs. 4D-E). At the Croce Valanidi section, the system shows a difference of $\sim 30^{\circ}$ in the dip between the lower and the upper strata. This geometrical relationship becomes less pronounced in the upwards portion of the succession where layers are almost sub-horizontal (Fig. 4E).

The most proximal and basal deposits recognized in the lower portion are characterised by gravel- to pebble-sized breccia and conglomerate clasts mixed with coarse-grained bioclastic fragments to form a 20 to $200 \mathrm{~cm}$ thick intervals (Facies 1). Upwards, beds are typically composed of coarse-grained bioclastic-siliciclastic sand and conglomerate gravel (Facies 2). In a proximal position ( $\sim 60 \mathrm{~m}$ away from the scarp), beds form packages consisting of structureless coarse-grained sandstone with clustered or scattered angular gravel clasts and non-graded or coarse-tail inversely graded matrix- to clastsupported conglomerate. Locally, these packages are separated by $50-$ to $200 \mathrm{~cm}$ thick layers of amalgamated sandstone with non-erosional bases (Fig. 6B). Three hundred meters away from the scarp, conformable strata pertaining to the Facies 2 are interrupted by discontinuous, massive to coarse-tail inversely graded conglomerate-sandstone packages (Facies 3). This deposit results in several channelized features forming 2 to $3 \mathrm{~m}$ thick event beds containing isolated large floating clasts (up to $100 \mathrm{~cm}$ in size) (Fig. 4F). The lateral equivalent of these events beds in more proximal position ( $70 \mathrm{~m}$ away from the scarp) consists of chute-fill backsets developed within an otherwise conformable and parallel-stratified succession (Fig. 4B). In distal position ( $\sim 50 \mathrm{~m}$ away from the scarp), deposits consist of structureless to stratified, fine- to medium-grained sandstone with floating subangular to subrounded pebbles (Facies 4; Figs. 4G). Intensely bioturbated intervals separate the structureless and 
laminated sandstones (Fig. 4H). The siliciclastic fraction consists mainly of metamorphic clasts mixed with a carbonate bioclastic component. The bioclastic fraction contains a mixture of cool-water carbonate factory (e.g. bryozoan, brachiopods, echinoids) and bathyal corals (e.g. Madrepora oculata, Lophelia pertusa, Desmophyllum cristalli, Isis sp.; Barrier, 1986).

The sedimentary facies are all indicative of gravity-driven sediment-transport events, such as highdensity turbidity currents, debris flows, and debris falls. Chute conduits are indicative of erosional events related to supercritical flows (Nemec, 1990; Ono and Plink-björklund, 2018). Outsized clasts may be emplaced by bipartite flows including basal dense flow and upper bypassing turbidity current (Postma et al., 1988) or by debris falls (Nemec, 1990). The siliciclastic fraction derives mainly from the exposed fault scarp, while the carbonate one results from the fragmentation of coeval in situ carbonate factories developed along the footwall and at the base of the scarp.

The unconformity separating the lower from the upper portion of the Vinco Calcarenitc Unit marks an abrupt change in the depositional architecture: from underlying fault-attached wedge to overlying tabular overpassing the fault plane (Fig. 4E). The upper portion is mainly aggradational and gently onlap against either the lower portion or the metamorphic substrate (Fig. 4E). Moreover, the upper portion contains wave-influenced sedimentary structures and lack of bathyal corals in the proximal area passing distally to current-dominated cross-strata migrating parallel to the paleomargin and related to the paleo Messina Strait suggesting the evolution to a shoal-type system characterised by reworking in its distal environments. For a detailed documentation of the sedimentological facies recognised in the upper and distal portion of the Vinco Calcarenites unit please refer to Longhitano (2018).

The presence of an extensive unconformity between the pre-rift (i.e. Peloritani-Aspromonte Unit and Miocene deposits) and the lowermost syn-rift base-of-scarp deposits along the Armo Fault suggests that the Armo system was already active during the deposition of the Vinco Calcarenites Unit (Fig. 4). We interpret that the landwards thinning recognized at the Croce Valanidi and San Teodoro sections 
towards the Armo Fault is related to the initiation of forced folding above this structure during the early syn-rift stage. The absence of deposits along the footwall can be both due to non-deposition (i.e. by-pass) or erosion. Important to highlight is that the area has been subject to a time-averaged throw rate of $0.7+0.3 /-0.2 \mathrm{~mm} \mathrm{a}^{-1}$ (Roda-Boluda and Whittaker, 2017) producing a fault throw of $\sim 350 \mathrm{~m}$.

The overall shallowing upward transition between the lower and the upper portion marks the change in the depositional architecture between the unsteady base-of-scarp deposits and the steady-state shelf-type delta suggesting that sediment-supply rate exceeded the fault-slip rate.

\section{DISCUSSION}

\section{Relationship between fault slip, sedimentation, and internal geometry}

The lower portion of the studied sections (i) onlap onto a tectonic scarp produced by extensional faults, (ii) lack sedimentary structures related to wave action and lateral equivalents typical of coastal marine or terrestrial facies, (iii) accumulate in a subaqueous setting below the storm-base as a body detached from a subaerial counterpart, (iv) contain bathyal corals suggesting that they have been deposited in a relatively deep-water setting, and (v) are characterised by an extremely low depth-ratio (sensu Jopling, 1965) defined as the ratio between the water depth at footwall edge and the water depth at the hanginwall (i.e. base of the scarp). Given this setting and the predominance of texturally immature sediment gravity-flow deposits, we infer that sediments were transferred through a proximal sediment bypass zone (sensu Stevenson et al., 2015) and experienced a very limited rework and transport before accumulated.

Even though in the literature the Civita section has been considered at basin-scale part of a vertically stacked Gilbert-type deltas (Colella, 1988a), we interpret that the lower portion of the system represents a separate base-of-scarp system onlapping against the controlling fault scarp without developing topsets facies. In the first documented field-based example, the Pollino Fault controlled 
the development of the Civita section, and an increase of the fault-slip rate exceeding the sedimentsupply rate may have caused, through remobilization of large portions of sediment and re-definition of the depositional profile highlighted by unconformity surfaces, the evolution from an unsteady baseof-scarp to a steady-state Gilbert-type delta (Fig. 8A). Unconformity surfaces interpreted by Colella (1988b) in the Civita section as erosional surfaces related to gravitational sliding of coarse-grained material linked to tectonic vertical displacement (Fig. 1B).
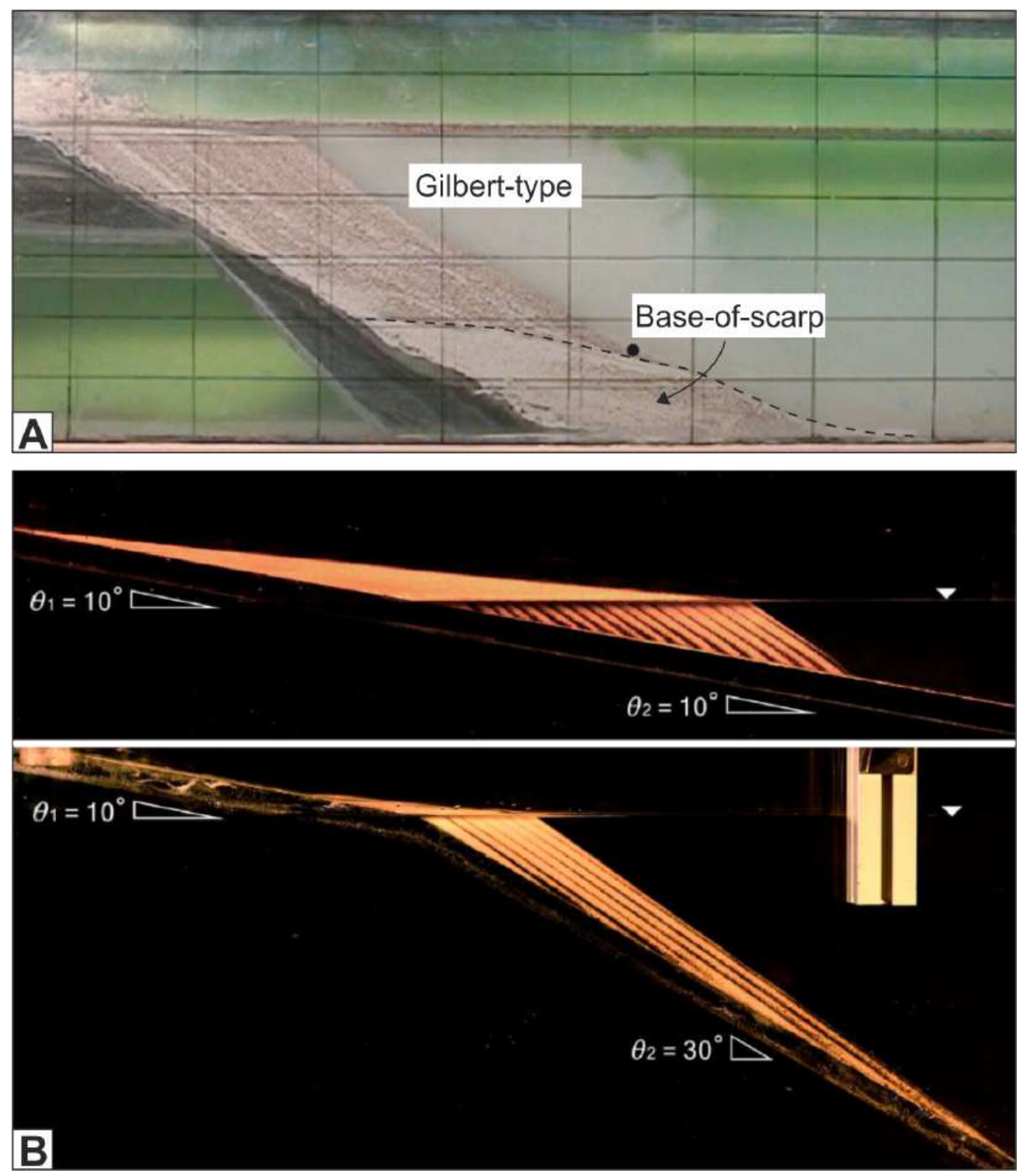

Figure 8-A) Flume experiment showing the development of base-of-scarp deposits during the early phases. Base-of-scarp deposits evolving to a Gilbert-type delta system on top of an unconformity separating the unsteady to the steady-state phases (modified after Abeyta and Paola, 2015). B) Profile of Gilbert-type deltas evolving above depositional surface characterised by different depositional angles (modified after Lai et al., 2017). 
The stratigraphic vertical evolution recognized in the Croce Valanidi and San Teodoro sections (Fig. 4) shows wedge-shaped deposits of the base-of-scarp lower portion passing upwards to sub-horizontal, finer-grained beds. This trend indicates that the base-of-scarp system gradually reduced the dip angle of its depositional profile from base to top (Fig. 5). Moreover, the recognised fining-upward trend differs markedly from the progradational coarsening-upward trend commonly suggested for deltaic successions (Miall, 1976) and alluvial fans (Steel et al., 1977), and is typical rather of colluvial systems (Nemec, 1990; Blikra and Nemec, 1998, Longhitano et al., 2015). The upwards transition from inclined to subhorizontal beds indicates that the lower portion of the Croce Valanidi and San Teodoro systems corresponds to a base-of-scarp deposits ("B" corner of the BGS triangle; Fig. 9), whereas the upper portion represents a transition to a shoal-water system (Fig. 4E). Transition suggesting that the upper portion develops when the controlling fault reduced its activity or became inactive, whereas it was clearly active during the deposition of the lower portion as suggested by growing of the foldpropagation fault responsible for the upwards change in the dip of the beds (Fig. 4D). The Croce Valanidi section occurs $\sim 1 \mathrm{~km}$ southwest along the Armo Fault, in respect to the San Teodoro section, and it represents mainly the "B" end-member (i.e. base-of-slope) of the fault-controlled system. The different behaviour of the San Teodoro and Croce Valanidi systems might reflect differential fault displacement along the fault scarp (fault tip versus centre) leading to different subsidence and faultactivity patterns (e.g. Barrett et al., 2019), or diachronous onset of the folding along strike (Lewis et al., 2015).

The development of unsteady base-of-slope deposits versus steady-state systems (e.g. Gilbert-type or shoal-water-type systems) seems to be mainly controlled by (i) the angle of the depositional slope above which sediments accumulate, (ii) fault activity, (iii) depth-ratio, and (iv) the ratio between the fault scarp displacement and the rate of sediment supply.

Experimental studies based on flume reconstructions (e.g. Lai et al., 2017) show that in order to initiate the development of Gilbert-type deltas the angle of the basal depositional slope typically is between 30 and 10 degrees (Fig. 8B), where the exact value depends from different aspects including the 
sorting, shape and grain-size of the sediments. Accordingly, for a given sediment with a specific texture the maximum angle of the depositional slope cannot be higher than its angle of repose. In contrast, shelf-type deltas develop along a depositional profile having an angle less than 5 degrees. (ii) Recurrence and magnitude of the fault activity play a major role in the evolution of fault-controlled systems since the creation of accommodation as well as the balance between depth ratio and sediment supply have an impact on the depth ratio. (iii) High versus low depth-ratio defines if the hanginwall deposits are likely attached or not to their footwall counterpart. In case of an extremely low depthratio as interpreted for the studied sections, the systems are characterised by a bypass zone along the fault scarp with sediments accumulated to form an unsteady base-of-scarp deposit. (iv) Finally, the accommodation versus sediment supply controls the achievement of conditions such that an unsteadystate systems may evolve into steady-state and vice versa through time.

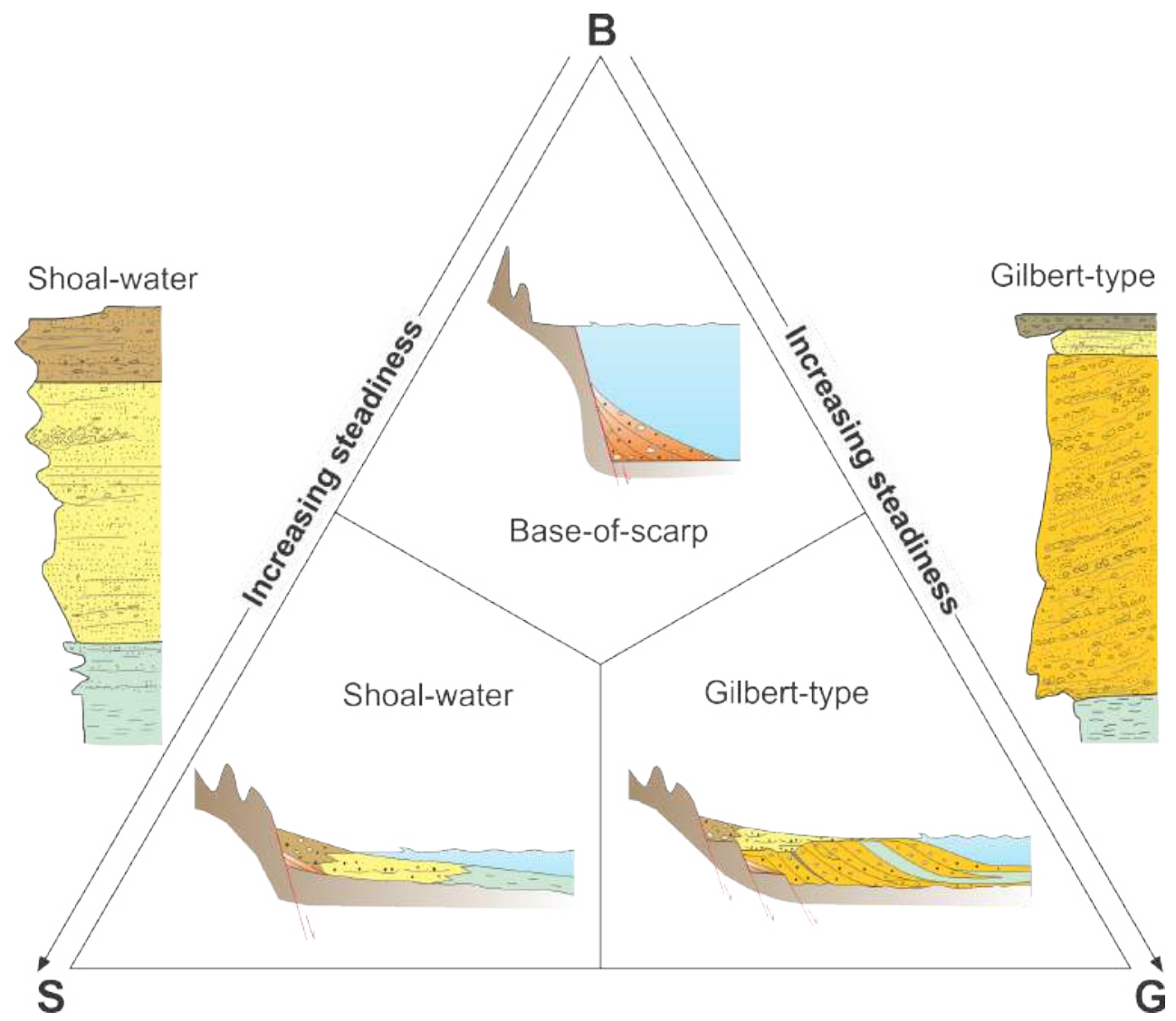

Figure 9 - BSG schematic diagram of fault-controlled systems. Base-of-scarp deposits (B) represents the unsteady-state end-member. The shoal-water $(S)$ and Gilbert-type $(G)$ represents the steady-state of faultcontrolled systems for which two representative vertical sequences are shown. Mixed systems can exist in the triangle depending on the interaction between sedimentary supply rate and accommodation. 
As reported by Bell et al. (2018) for the Corinth Rift, amagmatic rifts not affected by preexisting lowangle structures like the Crati and Messina rifts accommodate strain along high-angle faults (dipping $>30$ degrees). This statement support that during the early syn-rift phases the depositional slope in the studied areas may have had an angle not suitable for the development of steady-state systems (i.e. Gilbert-type or shoal-water-type deltas). Only a progressive accumulation of sediments as base-ofscarp deposits could set the equilibrium conditions (e.g. reduction of the angle of the depositional slope and high depth-ratio) to promote sediment accumulation in a steady-state. Equilibrium conditions that are controlled by the activity of the margin faults. In the study areas, several works (e.g. Colella, 1988b; Ghisetti, 1992; Spina et al., 2011; Roda-Boluda and Whittaker, 2017) documents that faults have been active during the deposition supporting that they have played a role into the development of the unsteady base-of-scarp deposits and their evolution towards a steady-state and vice versa. Unfortunately, there are no data to constrain possible paleodepth estimation for the lower portion of the Civita section. However, ecological information referred to the bioclasic fraction (i.e. coral fragments) recognised in the Croce Valanidi and San Teodoro sections suggest that the lower portion of the Vinco Calcarenites Fm accumulate in a bathyal condition with the step fault scarp working as bypass area.

For an unsteady base-of-scarp system to reach a steady-state (Fig. 10), sedimentation at the apex has to aggrade up or above the base level and the depositional slope to decrease to a critical angle (Nemec, 1990). Depending upon the ratio of the rates of fault slip and sediment supply, the unsteady systems can evolve through time into two possible scenarios. (i) At a relatively low fault-slip rate or highsediment supply, the base-of-scarp deposit may exhaust the tectonically-created accommodation and evolve into steady-state Gilbert-type or shoal-water delta, thus moving towards the base of the BGS triangle (Fig. 9) while passing through transitional unsteady-states (Fig. 4). (ii) At a relatively high faultslip rate or low sediment supply, the base-of-scarp deposit will be subject to protracted subaqueous aggradation and progradation remaining in an unsteady-state. 


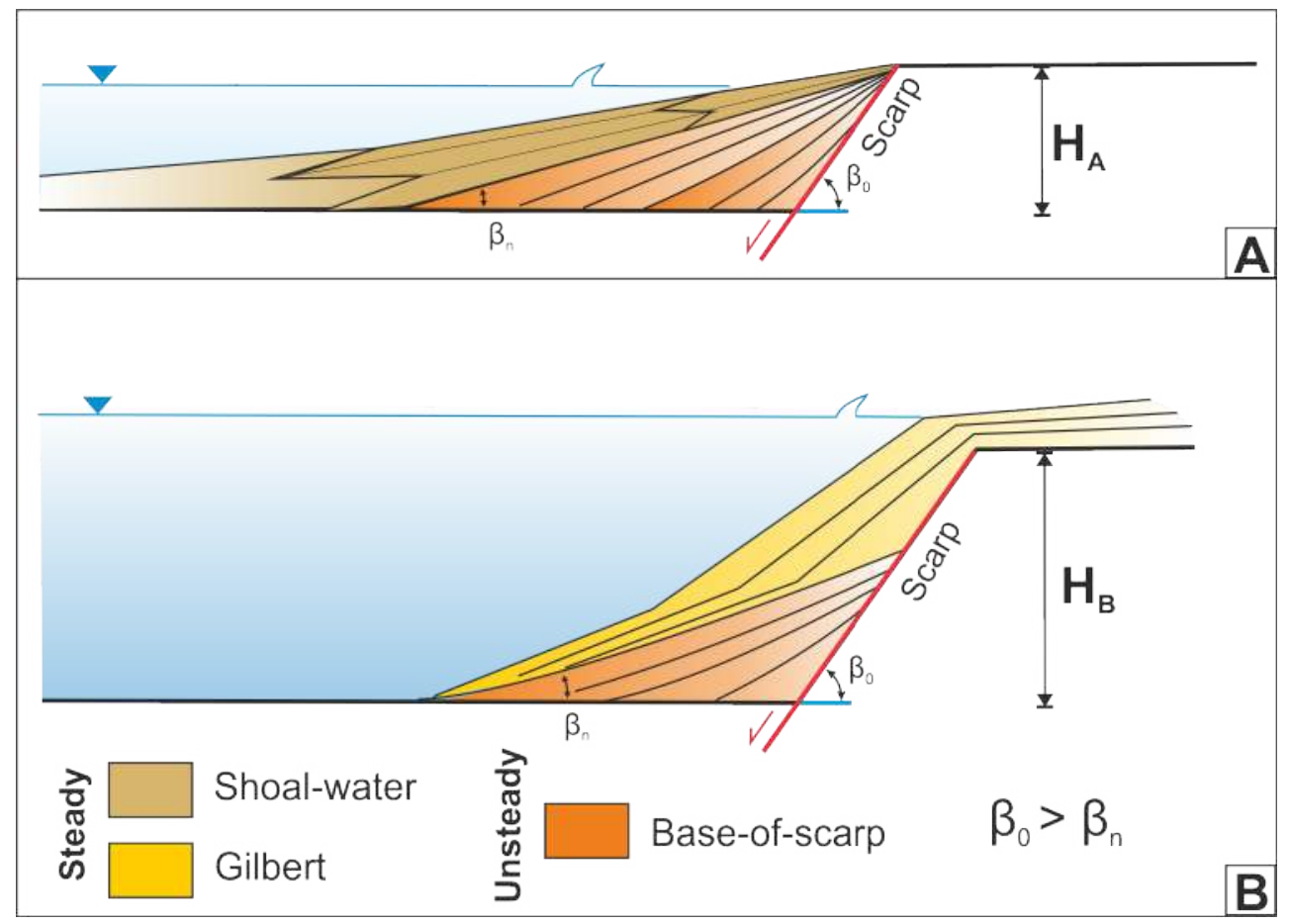

Figure 10 - Schematic representation of base-of-scarp deltas evolving into (A) shoal-water and (B) Gilbert type systems characterised by a steady-state condition. The progressively angle decrease recognised in younger strata promote the architectural change of the system. The transitional phase represents a hybrid system characterised by features typical of the end-member systems. " $\beta$ " indicates the depositional angle while " $H$ " represents the fault displacement.

\section{CONCLUSIONS}

The base-of-scarp deposits represent unsteady-state systems showing primary inclined bedding and aggradational to progradational geometries along active fault scarps. The base-of-scarp deposits form entirely subaqueously without a direct depositional connection with their subaerial or shallower counterpart located on the footwall. The non-depositional sector separating the source area from the base-of-scarp deposits represents a sediment bypass zone. The bedding geometry and spatial grainsize trend of base-of-scarp systems (B) differ markedly from those of the fault-controlled common Gilbert-type (G) and shoal-water (S) deltas. Main characteristic aspects consist on (i) progressive upwards decrease in strata dip, (ii) low depth-ratio, (iii) immature texture of the basal deposits evolving upward into slightly more mature and organized beds, (iv) fining-upward general trend and (v) dynamic evolution from unsteady- to steady-state systems and vice versa. 
On this basis, the base-of-scarp systems can be distinguished from possible erosional relics of Giberttype or shoal-type deltas in the stratigraphic record. As a rule, the base-of-scarp systems can reach a steady-state of development by evolving into a Gilbert-type (G) or shoal-water (S) delta once the sediment supply eventually outpaces the accommodation. Accordingly, sediment accumulation and related change into the depositional slope angle guide the system towards a new depositional style without any major change in the basin physiography.

\section{ACKNOWLEDGEMENTS}

This research is part of the "Fault-Controlled Deposits - Phase I" Joint Industry project sponsored by AkerBP, DNO, Neptune Energy and Spirit Energy. Thanks to W. Nemec for reading through an earlier version of this manuscript.

\section{REFERENCES}

Abeyta A. and Paola C. 2015. Transport dynamics of mass failures along weakly cohesive clinoform foresets. Sedimentology, 62, 303-313.

Barrett, B., Collier, R.E.L.L., Hodgson, D.M., Gawthorpe, R.L., Dorrell, R.M. and Cullen, T.M., 2019. Quantifying faulting and base level controls on syn-rift sedimentation using stratigraphic architectures of coeval fan deltas: constraining Early-Middle Pleistocene baselevel amplitude change in Lake Corinth. Basin Research, 31, 1040-1065.

Barrier, P., 1986, Evolution paleogeographic du detroit de Messine au Pliocene et au Pleistocene: Giornale di Geologia, v. 48, 7-24.

Bell R.E., Duclaux G., Nixon C.W., Gawthorpe R.L. and McNeill L.C., 2018. High-angle, not low-angle, normal faults dominate early rift extension in the Corinth Rift, central Greece. Geology, 46, 115118.

Blikra, L.H., and Nemec, W., 1998, Postglacial colluvium in western Norway: depositional processes, facies and paaeoclimatic record: Sedimentology, v. 45, 909-959.

Catalano S., De Guidi G., Monaco C., Tortorici G., Tortorici L. 2008. Active faulting and seismicity along the Siculo-Calabrian Rift Zone (Southern Italy). Tectonophysics, 453, 177-192.

Colella, A., 1988a, Fault-controlled marine Gilbert-type fan deltas: Geology, v. 16, p. 1031-1034.

Colella, A., 1988b, Pliocene-Holocene fan deltas and braid deltas in the Crati basin: a consequence of varying tectonic conditions, in Nemec, W. and Steel, R.J. eds., Fan Deltas: Sedimentology and Tectonic Settings, London, Blackie and Son Ltd, p. 50-74.

Catalano, R., Monaco, C., Tansi, C. 1993. Pleistocene strike-slip tectonics in the Lucanian Apennine (Southern Italy). Tectonics 12, 56-65.

Chiarabba, C., Agostinetti N.P., Bianchi I. 2016. Lithospheric fault and kinematic decoupling of the Apennines system across the Pollino range. Geophysical Research Letters, 43, 3201-3207. 
Chiarella, D., 2016. Angular and tangential toeset geometry in tidal cross strata: an additional feature of current-modulated deposits. In: Tessier, B., Reynaud, J.-Y. (Eds.), Contributions to Modern and Ancient Tidal Sedimentology: Proceedings of the Tidalites 2012 Conference. IAS Special Publicationpp. 185-195.

Chiarella, D., Longhitano, S.G., 2012. Distinguishing depositional environments in shallow-water mixed, bio-siliciclastic deposits on the basis of the degree of heterolithic segregation (Gelasian, southern Italy). J. Sediment. Res. 82, 969-990.

Chiarella D., Longhitano S., Sabato L., and Tropeano M., 2012. Sedimentology and hydrodynamics of mixed (siliciclastic-bioclastic) shallow-marine deposits of Acerenza (Pliocene, Southern Apennines, Italy). Boll. Soc. Geol. It., 131, 136-151.

Chiarella, D., Longhitano, S.G., and Tropeano, M., 2017. Types of mixing and heterogeneities in mixed siliciclastic-carbonate sediments: Marine and Petroleum Geology, 88, 617-627.

Chiarella, D., Longhitano, S.G., and Tropeano, M., 2019. Different stacking patterns along an active fold-and-thrust belt-Acerenza Bay, Southern Apennines (Italy). Geology, 47, 139-142.

Cullen T.M., Collier R.E.LI., Gawthorpe R.L., Hodgson D.M. and Barrett B.J. in press, Axial and transverse deep-water sediment supply to syn-rift fault terraces: Insights from the West Xylokastro Fault Block, Gulf of Corinth, Greece. Basin Research

Dorsey R.J., Umhoefer P.J., Renne P.R: !995. Rapid subsidence and stacked Gilbert-type fan deltas, Pliocene Loreto basin, Baja California Sur, Mexico. Seidmentary Geology, 98, 181-204.

Ethridge, F.., and Wescott, W.., 1984, Tectonic Setting, Recognition and Hydrocarbon Reservoir Potential of Fan-Delta Deposits, in Koster, E.H. and Steel, R.J. eds., Sedimentology of Gravels and Conglomerates, CSPG Special Publications, v. 10, p. 217-235.

Ferranti, L., Santoro, E., Mazzella, M.E., Monaco, C., Morelli, D. 2009. Active transpression in the northern Calabria Apennines, southern Italy. Tectonophysics 476, 226-251.

Garcia-Garcia F., Fernandez J., Viseras C. and Soria J.M. 2006. Architecture and sedimentary facies evolution in a delta stack controlled by fault growth (Betic Cordillera, southern Spain, late Tortonian). Sedimentary Geology, 185, 79-92.

Ghisetti, F. 1979. Evoluzione neotettonica dei principali sistemi di faglie della Calabria centrale: Boll. Soc. Geol. Ital., 98, 387-430.

Ghisetti, F., 1984. Recent deformations and the seimogenic source in the Messina Strait (Southern Italy). Tectonophysics 109, 191-208.

Ghisetti, F., 1992. Fault parameters in the Messina Strait (southern Italy) and relations with the seismogenic source. Tectonophysics 210, 117-133.

Ghisetti, F., Vezzani, L., 1982. Strutture tensionali e compressive indotti da meccanismi profondi lungo la linea del Pollino (Appennino meridionale). Bollettino della Società Geologica Italiana, 101, 385440.

Gobo, K., Ghinassi, M., and Nemec, W., 2015, Gilbert-type deltas recording short-term base-level changes: Delta-brink morphodynamics and related foreset facies: Sedimentology, v. 62, p. 1923 1949, doi:10.1111/sed.12212.

Hardy, S., Dart, C.J., and Waltham, D., 1994, Computer modelling of the influence of tectonics on 
sequence architecture of coarse-grained fan deltas: Marine and Petroleum Geology, v. 11, p. 561-574, doi:10.1016/0264-8172(94)90068-X.

Henstra G.S., Grundvåg S.A., Johannessen E.P., Kristensen, T.B., Midtkandal I., Nystuen J.P., Rotevatn A., Surlyk F., Sæther T. and Windelstad J. (2016) Depositional processes and stratigraphic architecture within a coarsegrained rift-margin turbidite system: The Wollaston Forland Group, east Greenland

Jia, Y., Lin, C., Eriksson, K.A., Niu, C., Li, H., Zhang, P., 2019. Fault control on depositional systems and sequence stratigraphic architecture in a multiphase, rifted, lacustrine basin: A case study from the paleogene of the central Bohai Bay Basin, northeast China. Marine and Petroleum Geology, 101, 459-475.

Jopling, A.V., 1965, Hydraulic factors controlling the shape of the laminae in laboratory deltas. Journal of Sedimentary Petrography, v. 35, 777-791.

Lai S.Y.J., Hsiao Y.-T. and Wu F.-C., 2017. Asymmetric Effects of Subaerial and Subaqueous Basement Slopes on Self-Similar Morphology of Prograding Deltas. Journal of Geophysical Research:Earth Surface, 122, 2506-2526.

Leeder, M.R. \& Gawthorpe, R.L. (1987) Sedimentary models for extensional tilt-block/half-graben basins. In: Continental Extensional Tectonics (Ed. by M.P. Coward, J.F. Dewey \& P.L. Hancock), Geol. Soc. London Spec. Publ., 28, 139-152.

Lewis, M.M., Jackson, C.A.-L., Gawthorpe, R.L., Whipp, P.S., 2015, Early synrift reservoir development on the flanks of extensional forced folds: A seismic-scale outcrop analog from the Hadahid fault system, Suez rift, Egypt: AAPG Bulletin, 99, 985-1012.

Longhitano, S.G., 2018, Between Scylla and Charybdis: The sedimentary dynamics of the ancient, Early Pleistocene Messina Strait (central Mediterranean) based on its modern analogue: Earth-Science Reviews, 179, 248-286.

Longhitano, S.G., Chiarella, D., Muto, F., 2014. Three-dimensional to two-dimensional cross-strata transition in the lower Pleistocene Catanzaro tidal strait transgressive succession (southern Italy). Sedimentology, 61, 2136-2171.

Longhitano, S.G., Sabato, L., Tropeano, M., Murru, M., Carannante, G. 2015. Outcrop reservoir analogous and porosity changes in continental deposits from an extensional basin: the case study of the upper Oligocene Sardinia Graben System, Italy. Marine and Petroleum Geology 67, 439459.

Longhitano, S.G., Chiarella, D., Di Stefano, A., Messina, C., Sabato, L., Tropeano, M., 2011. Neogene to Quaternary tidal mixed deposits of southern Italy: implications for palaeogeographic reconstructions. Rend. Online Soc. Geol. It. 17, 123-128.

Massari, F., and Colella, A., 1988, Evolution and types of fan-delta systems in some major tectonic settings, in Nemec, W. and Steel, R.J. eds., Fan Deltas: Sedimentology and Tectonic Settings, London, Blackie and Son Ltd, p. 103-122.

Massari F. and Chiocci F.L., 2006. Biocalcarenite and mixed cool-water prograding bodies of the Mediterranean Pliocene and Pleistocene: architecture, depositional setting and forcing factors. In: "Cool-Water Carbonates: Depositional Systems and Palaeoenvironmental Controls" (H.M. Pedley \& G. Carannante, eds.), London Geol. Soc., Spec. Publ., 255, 95-120.

Miall, A.D., 1976, Facies Model 4, Deltas: Geoscience Canada, v. 3, 215-227. 
Monaco, C., Tansi, C., 1992. Strutture transpressive lungo la zona trascorrente sinistra nel versante orientale del Pollino (Appennino calabro-lucano) (Transpressional structures along the left-lateral strike-slip zone on the eastern slope of Mt. Pollino (Calabrian-Lucanian Apennine)). Bollettino della Societ`a Geologica Italiana 111, 291-301.

Monaco, C., and Tortorici, L., 2000, Active faulting in the Calabrian arc and eastern Sicily: Journal of Geodynamics, v. 29, p. 407-424.

Monaco, C., Tortorici, L., Nicolich, R., Cernobori, L., Costa, M., 1996. From collisional to rifted basins: an example from the southern Calabrian arc (Italy). Tectonophysics 266, 233-249.

Nalin R., Ghinassi M., Foresi L.M., Dallanave E., 2016. Carbonate Deposition in restrcited basins: A Pliocene case study from central Mediterranena (Northwestern Apennines). Journal of Sedimentary Research, 86, 1-32.

Nemec, W., 1990, Aspects of Sediment Movement on Steep Delta Slopes, in Colella, A. and Prior, D.B. eds., Coarse-Grained Deltas, IAS Special Publication 10, p. 29-73.

Ono, K., and Plink-Björklund, P., 2018, Froude supercritical flow bedforms in deepwater slope channels? Field examples in conglomerates, sandstones and fine-grained deposits: Sedimentology, v. 65, p. 639-669.

Pepe M. and Gallicchio S., 2013, Shallow-marine systems in a wedge-top basin setting: an example from the middle-upper Pliocene deposits of the Southern Apennines mountain front (Basilicata region, South Italy). Ital. J. Geosci. (Boll. Soc. Geol. It.), 132, 304-320.

Postma, G., Nemec, W., and Kleinspehn, K.L., 1988, Large floating clasts in turbidites: a mechanism for their emplacement: Sedimentary Geology, v. 58, p. 47-61, doi:10.1016/0037-0738(88)90005-X.

Prior, D.B., and Bornhold, B.D., 1988, Submarine morphology and processes of fjord fan deltas and related high-gradient systems: modern examples from British Columbia, in Nemec, W. and Steel, R.J. eds., Fan Deltas: Sedimentology and Tectonic Settings, London, Blackie and Son Ltd, p. 103122.

Roda-Boluda D.C., and Whittaker A.C. 2017. Structural and geomorphological constraints on active normal faulting and landscape evolution in Calabria, Italy. Journal of the Geological Society, v. $174,701-720$.

Rossi, V.M., Longhitano, S.G., Mellere, D., Dalrymple, R.W., Steel, R.J., Chiarella, D., Olariu, C., 2017. Interplay of tidal and fluvial processes in an early Pleistocene, delta-fed strait margin (Calabria, Southern Italy). Marine and Petroleum Geology, 87, 14-30.

Spina, V., Tondi, E., \& Mazzoli, S. (2011). Complex basin development in a wrench-dominated back-arc area: Tectonic evolution of the Crati Basin, Calabria, Italy. Journal of Geodynamics, 51, 90-109.

Stearns, D. W., 1978, Faulting and forced folding in the Rocky Mountain foreland. Geological Society of America Memoirs, v. 151, p. 1-38, doi:10.1130/MEM151.

Steel, R.J., Moehle, S., Nilson, H., Roe, S.L. and Spinnangre, A. 1977. Coarsening upwards cycles in the alluvium of Homelen Basin (Devonian), Norway: sedimentary response to tectonic events: Bulletin of the Geological Society of America, v. 88, 1124-1134.

Stevenson C.J., Jackson C. A.L., Hodgson D.M., Hubbard S.M. and Eggenhuisen J.T., 2016. Deep water sediment bypass. Journal of Sedimentary Research, 85, 1058-1081. 
Surlyk, F., 1984. Fan-delta to submarine fan conglomerates of the Volgian-Valanginian Wollaston Forland group, east Greenland. In: Koster, E.H., Steel, R.J. (Eds.), Sedimentology of Gravels and Conglomerates, pp. 359e382. Mere. Can. Soc. Pet. Geol. 10.

Tansi, C., Muto, F., Critelli, S., lovine, G., 2007. Neogene-Quaternary strike-slip tectonics in the central Calabrian Arc (southern Italy). Journal of Geodynamics 43, 393-414.

Turco, E., Maresca, R., Cappadona, P., 1990. La tettonica plio-pleistocenica del confine calabro-lucano: modello cinematico (Plio-Pleistocene tectonics at the Calabrian-Lucanian boundary: a kinematic model). Memorie della Societ`a Geologica Italiana 45, 519-529.

Turner C.C. and Connell E.R. (2018) Mid to Late Jurassic Graben margin development and evolution of shallow marine to submarinefan systems in the Brae area south of south Viking Graben, UK North Sea. AAPG Memoir 115, 163-211.

Van Dijk, J.P., Bello, M., Brancaleoni, G.P., Cantarella, G., Costa, V., Frixa, A., Golfetto, F., Merlini, S., Riva, M., Torricelli, S., Toscano, C., Zerilli, A., 2000. A regional structural model for the northern sector of the Calabrian Arc (southern Italy). Tectonophysics 324, 267-320.

Yesares-García J. and Aguirre J. 2004. Quantitative taphonomic analysis and taphofacies in lower Pliocene temperate carbonate-siliciclastic mixed platform deposits (Almeria-Nijar Basin, SE Spain). Palaeogeogr Palaeoclimatol Palaeoecol, 207, 83-103. 